The Philosophical Journal of Conflict and Violence

Vol. I, Issue 2/2017

(C) The Authors, 2017

Available online at http://trivent-publishing.eu/

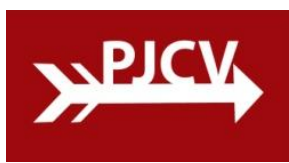

\title{
Losurdo, Domenico. Non-Violence: A History beyond the Myth
}

Lanham: Lexington Books, 2015. vii + 246 pp.

Domenico Losurdo, in his book Non-Violence: A History Beyond the Myth, aims to demonstrate the historical contradictions of non-violent action. This book embraces two centuries of the history of non-violence, reconstructing the great historical crises that this movement has faced from its inception. In his analysis, Losurdo does not limit himself to a history of the ideas, but instead investigates theories, political opinions, contradictions, moral dilemmas, and concrete behaviors in the context of central historical crises and transformations.

Losurdo affirms that the popularity of non-violence movements is in part based on frustration with wars and revolutions that promised to achieve a state of perpetual peace by implementing their different methods. In other words, violence was used to guarantee the eradication of the scourge of violence once and for all. The First World War was greeted by mass enthusiasm to enlist in "the war to end all wars." Similarly, the revolution in Russia was expected to overcome the brutality of capitalist exploitation and war. Therefore, we are familiar with the blood and tears that have dirtied projects to change the world through war or revolution, but what do we know of the dilemmas, "betrayals," disappointments, and veritable tragedies that have befallen the movement inspired by the ideal of non-violence (5)?

The author recognises that the first group committed to build a socio-political order characterized by non-violence was the Christian abolitionists in the United States in the nineteenth century. Moreover, the American Peace Society and the Non-Resistance Society considered it possible to solve the problem of violence by rediscovering the "original" Christian message and its progressive penetration of popular consciousness. First, it was asserted that the Gospel's message could only be restored in its purity by clearly distancing oneself from the Old Testament and the theme, well-attested in it, of holy wars or wars of the Lord. Second, God had not restricted the precepts of the gospel to individuals; they also applied to states. Condemnation of war and violence in any shape or form must be concretely realized at a social level. In 1812, David L. Dodge, a fervent Christian, published the book War Inconsistent with the Religion of Jesus Christ that might be regarded as the first manifesto of the nascent non-violent movement. He argues that we should abstain from violence, even indirect participation in it, in all circumstances. Indeed, the spirit of 
martyrdom is the true spirit of Christianity. For this reason, it is criminal to approve any action that contradicted the Sermon on the Mount and presumed to legitimize violence.

However, Losurdo points out the kind of dilemmas facing non-violence movements such as the American Peace Society in the 1860s: when the South broke from the North, was the Society to help crush the rebellion or accept the violence inherent in slavery? It seems that non-violence as a principle is easily fractured when its leading protagonists are forced to make critical political choices. The American Civil War brought this philosophical crisis as it became clear that only force would break slavery in the southern states. A paradigmatic example of this dilemma was Charles Stearns, one of the strictest figures in the non-violent and abolitionist movement (13). In 1855, he affirmed that it is always practicable to be a non-resistant; and to refuse obedience to the devil. However, an irrevocable crisis came: could the advocates of non-violence accept the expansion of slavery, as well as the killing of those who sought to oppose it, without reacting? Stearns decided to take part to the armed struggle. He affirmed that he was not in contradiction with the principle of absolute inviolability of human life, because slave owners were not subsumable under the category of man. Hence, armed struggle, it was decided, was the lesser of the two evils. However, as it can be seen in the dehumanization of the enemy, violence has not been diminished, Stearns applied a watchword like those who used "redskins!"

More measured, perhaps, was Henry David Thoreau (17). At the time of the United States invasion of Mexico, Thoreau had likewise called for resistance to war and slavery. The revolution invoked was not armed rebellion, but "civil disobedience." Thoreau had no difficulty in making the transition from "civil disobedience" interpreted as "peaceable revolution" to resolute moral and political support for Brown, the armed prophet of the desired rebellion by the southern slaves. This case shows that it was common to see rejection of violence turned into a pronounced consecration of violence itself.

The emblematic figure of Gandhi is obviously the one of the protagonist in Losurdo's inquiry. Nonetheless, the author gives an unfamiliar portrait of Gandhi's philosophy. In fact, he remarks his attitude toward the war and military life in general. Gandhi expressed admiration for the military virtue not only of the British, but also of the enemy. The early Gandhi was so intent on garnering support for the rights of Indians that he not only supported the British in South Africa against the Zulu revolt in 1906 - Indians were part of the "civilized" settled minority - but he later became one of the chief recruiting agents for the British Army in India during the First World War.

In other words, far from being condemned as such, when violence was synonymous with courage and heroism, it was admired regardless of war aims. How did Gandhi reconcile the extreme violence of the war with the doctrine of abimsa (the practice of non-violence towards every sentient being) that he started to formulate during this period? He argued that Indians had to prove their warlike valour and virility; otherwise they would forever remain "niggers" in the eyes of the British. Violence was only condemned in Gandhi's thinking at this stage when it occurred between Indians and the British (33).

Two events led to the definitive crisis of this intellectual and political platform, and caused Gandhi's transition from aspiring for the co-option of Indians to demanding general 
recognition and emancipation. On the one hand, the October Revolution, and the spread of Communist agitation in the colonies. But a decisive role was played above all by a direct, painful experience for the Indian people. By the end of the war a million Indian volunteers had travelled to fight on Britain's side, for which they were rewarded with the Amritsar Massacre. The Amritsar Massacre not only took the lives of hundreds of unarmed Indians, but also involved a terrible national and racial humiliation, with the inhabitants of the rebel city being obliged to crawl on all fours to return home or to get out (71). Gandhi's desire for Indians to be co-opted into the dominant (English) race had proved futile.

After this dreadful massacre, Gandhi promoted the faith in abimsa. To make India the embodiment of abimsa, Gandhi had to engage in an "invention of tradition." He could appeal to Jainism for ahimsa, the vegetarian diet and condemnation of violence against any living being. Dilation of the concept of violence goes yet further in Gandhi: likewise, railways, industry, urbanization, and the destruction of traditional rural society are synonymous with subjection, enslavement, and violence. Even medicine was not safe from such outright condemnation. To conclude, according to Gandhi, modernity was much worse and much more violent than the world preceding it.

Thanks to the superior principle of non-violence embodied by it, India was invested with a redemptive mission. The profession of faith in non-violence and the claim for the moral primacy of the people who embodied this religion, once ancient and new, were closely interconnected. It was a kind of national and religious dogma. Furthermore, nonviolence became a technique for creating moral indignation.

In 1930, during the Salt March, the non-violent demonstrators penetrated en masse into salt basins defended by Indian police under the command of British officers. They knew that they were performing an illegal act that would meet with a response from the forces of order. Yet, Gandhi's party militants were not only not to react to the police blows, but had to surrender themselves, avoiding even the spontaneous gesture of using their arms to protect their faces, which were being bloodied by the sticks with steel points employed by the police. This was the sophisticated technique that made everything seem like a clash between martyrs and butchers: an undoubtedly "harrowing" spectacle that did not fail to arouse moral indignation (80). They provoked police repression, making it seem unjustified and cruel.

Losurdo declares that nonviolence was primarily an instrument for generating moral indignation, which was intended to solidify one's own side, while discrediting, isolating, and causing a crisis on the other side. It remains the case that possibly no one before Gandhi had understood so clearly the key role that moral indignation can play in a political conflict.

The celebration of abimsa allowed Gandhi to demand his country's independence for a morally superior civilization to that represented by the dominant colonial power and the West as such. However, if industrialism and mechanization were synonymous with violence, the return to the land and rural existence sponsored (or, rather, propagandized) by fascism entailed a certain reduction of violence, even if the latter experienced expansion and exacerbation at the level of political relations. Ultimately, the condemnation of violence in principle risks taking the form in Gandhi of a night in which all cows are black (104). 
Martin Luther King was another leading figure of the non-violence movement. In King's denunciation of the "appalling condition" of the black people, and "the unspeakable horrors of police brutality" which they continue to be subject to, went hand in hand with a passionate profession of faith in non-violence. Unlike in Gandhi, non-violence in King was not a "national" religion to be recovered; and it did not presuppose the practice of vegetarianism, understood as a form of respect for every living being (112). The position of African Americans was different than the position faced by the second Gandhi. AfricanAmericans were a minority and could not hope to shut down the whole country. Nevertheless, in this circumstance we also encounter the same ethical problem involved in the Salt March: the problem of non-violence liable to induce violence by the adversary against innocent victims and thus generate the moral indignation required to discredit and isolate the adversary.

In the following chapters, Losurdo examines the significant influence that Gandhi had in the West. He focuses his attention on the other leaders of the movement, such as Aldo Capitini and Danilo Dolci. In both cases, Gandhi's influence was huge. In Capitini, admiration towards the leader of the Indian independence movement was amplified with opposition to a regime- the fascist regime-engaged in constructing a colonial empire. In fact, during the Fascist period, he was very active in anti-fascist actions. Capitini was imprisoned twice for five months. The commitment to non-violence remained firm. Capitini, influenced by Gandhi, believed that nonviolence should embrace all creation and he consequently became a vegetarian. Danilo Dolci chose Sicily for his non-violent struggle in defence of labour and against the mafia. The non-violent faith was primarily a denunciation of the inherently violent character of the socio-political relations that existed internationally. In Dolci, the non-violent approach was based on the idea that human conflicts can be resolved in a way that minimises suffering and material destruction, while improving the resolution of conflict in a comprehensive and equitable way.

In chapter nine, Losurdo affirms that the so-called "color revolutions" demonstrate that even a noble ideal like non-violence can be easily exploited with a malicious intention. The term "color revolutions" was widely used by worldwide media to describe various nonviolence movement. The methods to be followed are described in a book published by the Albert Einstein Institution in the United States. This is a practical manual of agitation for a "realistic nonviolent struggle" against "dictatorships or [military] occupations." What immediately emerges in this "non-violent" manual is the military language. The target is not necessarily a dictator, but it might also be a government that enjoys wide or considerable support. The aim is not an improvement in existing political and social relations, but the conquest of power.

In conclusion, thanks to this text, the history of non-violence movement is considered behind the screen of the sympathies for the movement. Losurdo, in a scathing critique of Gandhi, around which most of this book is centred, underlines the ethical inconsistencies and moral ambiguities which pave the road of non-violence. The author affirms that nonviolent philosophy is based on a false counter-position that we can choose between violence and non-violence. Instead, historical crises repeatedly force people to choose between two different forms of violence, that of the rulers and that of the ruled. We find proof of the 
rule that condemnation of violence as such makes it difficult or impossible to distinguish between different manifestations and modalities of it. In particular, Losurdo demonstrates that the boundaries between violence and non-violence are fluid and problematic. From this, we can affirm that the history of non-violence movement is not a peaceful one.

Verbena Giambastiani

University of Pisa, Italy

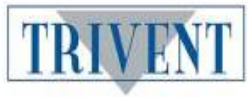

The PJCV Journal is published by Trivent Publishing. 